\title{
"Vergänglichkeit", de Hermann Hesse, em tradução direta do alemão para o português ${ }^{1}$
}

Mariana Silva de Campos Almeida

\section{$\mathrm{O}$ artista e seu texto poético}

O escritor, poeta e crítico literário Hermann Hesse (1877-1962) foi um homem de seu tempo, um dos expoentes da literatura européia da primeira metade do século 20 . Hesse buscava a identidade do homem contemporâneo num mundo marcado por crises; foi influenciado pela psicanálise e sua expressão artística refletia a significação de suas vivências pessoais, que o orientavam em sua busca pela essência do ser humano e da vida.

Segundo Zeller (2005), um de seus principais biógrafos, o poema "Vergänglichkeit" foi escrito após a Primeira Guerra Mundial (1914-1918) e publicado em 1920, no livro Caminhada² (Wanderung), ilustrado pelo próprio Hesse. Em sua curta autobiografia, escrita em 1924 e revista na época do recebimento do Nobel de Literatura de 1946 (HESSE, 1992, p. 16-17), Hesse se refere à primavera de 1919 como o fim de sua guerra particular, se refugiando como imigrante na Casa Camuzzi em Montagnola, onde vivia rodeado por um jardim de árvores frondosas.

Em seu recomeço, como ele próprio conta, Hesse quase deixou de acreditar em ser poeta e escritor, buscando consolo na bebida, pois seu trabalho não o deixava mais contente. Foi então que, 
Mariana Silva de Campos Almeida. "Vergänglichkeit", de Hermann Hesse, em ...

com quarenta anos, começou a pintar. A nova atividade lhe trouxe paciência e alegria e confirmou sua vocação artística. Era sua eterna necessidade de crescer e mudar.

Hermann Hesse é um dos autores alemães mais traduzidos e lidos no Brasil, embora a maior parte de sua obra tenha sido publicada na década de $1970^{3}$ e se encontre esgotada. ${ }^{4}$

\section{Vergänglichkeit}

Vom Baum des Lebens fällt

Mir Blatt um Blatt,

O taumelbunte Welt,

Wie machst du satt,

Wie machst du satt und müd,

Wie machst du trunken!

Was heut noch glüht,

Ist bald versunken.

Bald klirrt der Wind

Über mein braunes Grab,

Über das kleine Kind

Beugt sich die Mutter herab.

Ihre Augen will ich wiedersehn,

Ihr Blick ist mein Stern,

Alles andre mag gehn und verwehn,

Alles stirbt, alles stirbt gern.

Nur die ewige Mutter bleibt,

Von der wir kamen,

Ihr spielender Finger schreibt

In die flüchtige Luft unsre Namen. 


\section{Transitoriedade}

Cai-me da árvore da vida

Folha por folha,

Oh mundo, vertigem colorida!

Como me sacia,

Como sacia e cansa

Como me inebria!

Hoje a chama mansa

Logo jaz em sombra fria.

Em breve zune o vento

Sobre minha cova rubra,

Sobre seu rebento

A mãe se debruça.

Os olhos dela quero rever,

Seu olhar é minha sorte,

Tudo pode partir e se perder,

Tudo morre, tudo tende à morte.

Só a grande mãe é eterna,

Seu ventre nos fez homem,

Seu dedo rabisca feito pena

No céu fugaz nosso nome. 
Mariana Silva de Campos Almeida. "Vergänglichkeit", de Hermann Hesse, em ...

\section{Referências}

HESSE, H. Lesebuch. Frankfurt am Main: Suhrkamp, 1992. 403 pp.

ZELLER, B. Hermann Hesse. Hamburg: Rowohlt, 2005. 206 pp.

\section{Notas}

1 Esta tradução do poema "Vergänglichkeit" de Hermann Hesse, diretamente do alemão para o português, é resultado de um projeto tradutório desenvolvido ao longo do segundo semestre de 2008 na disciplina Prática em Tradução da PGET, ministrada pelo Prof. Dr. Markus J. Weininger, na PGET - 2/2008.

2 Publicado no Brasil pela editora Record, em 1978, com tradução de: Ildikó Maria Jávor.

3 Dados da editora alemã Suhrkamp encontrados em: http:/www.gss.ucsb.edu/projects/ hesse/publications/uebersetzungen-sprache.pdf Acesso em 26 fev 2010.

4 O leitor brasileiro encontra atualmente alguns poemas de Hesse no romance "O Jogo das Contas de Vidro" (Das Glasperlenspiel), traduzido por Lavínia Viotti e Flávio V. de Souza, publicado desde 1982 pela editora Record (proprietária dos direitos de tradução de Hesse no Brasil). 